\title{
Employing of Technical Assistants by Means of Micro Finance Factors
}

\author{
Anudevi, V.Sailaja, S.Binapani
}

\begin{abstract}
Self improvement gathering (SHG) is a town based money related delegate normally made out of 10- 20 nearby ladies. Most self improvement gatherings are situated in India, however SHGs can likewise be found in different nations, particularly in South Asia and Southeast Asia. Microfinance improves the socio-financial status of the Self-help gatherings. The point of microfinance program is to satisfy the monetary needs of low-salary bunches with the assistance of banks and it prompts the advancement of Self Help Groups. Research ponders on SHGs in the state uncovers that these gatherings comprised of for the most part 15-20 individuals for the most part having a place with in reverse territories of the general public. SHGs in India have turned into a potential instrument for the strengthening of ladies, social solidarity and financial advancement of the poor in their own setting. This paper frames some portion of a diagnostic research consider on the job of microfinance factors in the improvement of Self-help bunch in Tamil Nadu state. The examination was directed with an example of 560 individuals from self improvement gatherings having a place with various areas in Tamil Nadu, utilizing multistage inspecting and stratified testing. It has been discovered that the elements impacting self improvement gatherings are financial advantages, observation, gain profited, government disability, social association as for microfinance. It is prescribed that the assets ought to be used in the productive manner to create self improvement gatherings in the state.
\end{abstract}

Keywords : Microfinance, Self Help Groups, Socio-monetary advantages.

\section{INTRODUCTION}

Microfinance, by its name alludes the entire voyage of budgetary and non monetary administrations that spread ability up degree, business advancement rendered to poor people and destitute individuals to enable them to beat neediness. Microfinance alludes to credit; sparing, protection, exchange administrations and other money related items focused at low dimensions customers. Microfinance in India is primarily given through Self-Help Groups (SHGs), Microfinance Institutions (MFIs) and some different philosophies. The system of numerous money related organizations like open and private segment business banks, co-employable banks, territorial rustic banks (RRBs) and MFIs is utilized to give microfinance administrations to the destitute individuals. Microfinance program professes to

Revised Manuscript Received on December 11, 2019

Anudevi, Department of Science and Humanities, Bharath Institute of Higher Education and Research, Chennai , India. Email: Anudevi28@gmail.com

V.Sailaja, Department of Science and Humanities, Bharath Institute of Higher Education and Research, Chennai , India. Email: psaillajagmail.com

S.Binapani, Department of Science and Humanities, Bharath Institute of Higher Education and Research, Chennai, India. Email: bina.saravanangmail.com give the poor an entrance to capital and give them chances to climb the financial stepping stool[1]. The microfinance as a device in destitution decrease, improves financial states of poor people and strengthening especially in rustic regions. It is a strategy to meet the credit prerequisites in country territories. It puts credit, investment funds, protection and other essential money related administrations like store exchange (Robert et al, 2004) inside the scope of poor and low pay family unit and their microenterprises. Eventually, the objective of microfinance is to offer low pay individuals a chance to wind up independent by giving a methods for setting aside extra cash, acquiring cash and protection. NABARD has characterized smaller scale fund as pursues: "Miniaturized scale money is about arrangement of thrift, credit and other budgetary administrations and results of little add up to the poor in rustic, semi urban and urban territories for empowering them to raise their way of life." Micro account is an instrument to battle against destitution[2]. As indicated by Nobel Committee, smaller scale fund can assist the general population with breaking destitution, which thus is viewed as a vital essential to set up long last harmony.

\section{A. Objectives}

- To analyze the job of microfinance elements and SHG improvement in the province of Tamil Nadu.

- To examine the socio- financial advantages picked up by SHGs from profiting microfinance help from the business banks in the state.

- To break down the general execution of SHGs.

- To think about the smaller scale account loaning rehearses received by nationalized open segment business banks in stretching out credit to miniaturized scale endeavors.

- To break down the past execution of business banks in stretching out monetary administrations to SHG's[3].

\section{REVIEW OF LITERATURE}

Singh (2006)conducted an examination on SHGs program of Peoples Education and Development Organization and makes an endeavor to assess social and financial effect on family units of SHGs individuals. They found that the individuals associated with SHGs program have expanded inclusion in basic leadership, mindfulness about different projects and associations. In addition, the individuals get data about the diverse wellsprings of credit and expanded way of life. P.K.Singh, led an examination in Uttar Pradesh looking at the pre and post SHG circumstances of ladies SHGs. 
He saw that the estimation of benefits expanded by $46 \%$ and the yearly salary per family by $28 \%$ among pre and post SHG periods. They obtain for utilization reason amid pre SHG however it was totally missing in the post SHG circumstance.

B. Revathy\& M. Kailash (2012): The examination led in Guntur area of Andhra Pradesh uncovered that smaller scale fund has positive effect on the SHG individuals who increment their self-assurance, courage,self regard, socialbenefits and resource creation. This examination uncovered that microfinance improves the financial states of individuals in self improvementgroups.Sivasubramanian (1999)reveals that the investigation had focused on the disposal of neediness as real destinations of Indian advancement system. In 1993, the beneath destitution line was 36 percent. The BPL information which worked out of 320 million individuals, 224 million live in country regions. The rate of neediness had declined from54.9 percent in 1973-74 to 36 percent in 1993-94. The remarkable highlights of antipoverty programs are confined under different plans to bring development. In 1999, the improved plan of Swarnajayanthi Gram SwarozgarYojana (SGSY) would be focused on the idea of SHGs and group approach for connecting the poor as a powerful vehicle. Destitution can be mindfully annihilated just when the poor begin adding to the development procedure through a procedure of social activation, participatory methodology and strengthening of poor people. He reasons that microfinance considerably adds to decrease of neediness, when it is given fitting consideration in the provincial zones[4]-[6].

Pitt \&Khandker (1998) examined the effect of microfinance on neediness in Bangladesh. The examination demonstrated that the destitution rate of BRAC (Bangladesh Rural Advancement Committee, set up in 1970) individuals tumbled down. This rate of neediness decrease began tominimise with the term of enrollment and with total credit estimate. From this examination it is seen that the destitution is declined with the utilization of micro finance. Anjugam\&Alagumani (2001) inferred that microfinance has gotten impressive improvement basic leadership aptitudes among ladies, makes them trust in dealing with the money related emergency of the family, basic leadership limit in family matters and confidence in challenging social indecencies like drinking water issue, share and betting etc.Cheston\&Susy (2006) found that in numerous MFIs, ladies have turned out to be favored customers as their salary benefits their families through improved nourishment, wellbeing, instruction and economic wellbeing and for the prosperity of the country; because of better execution of the ladies in the gathering loaning projects and brief installment of credit sum the inclination is given to women. Allen et al (2007) finish up thatin dislike of an extensive financial division, about $40 \%$ of the Indian populace does not have ledgers. over $75 \%$ of the Indian populace still lives underneath $\$ 2$ per day, and a lion's share in rustic territories beneath the neediness line, micro finance the arrangement of

thrift reserve funds, credit and other budgetary items and administrations at a very scale to poor people and penniless to empower them to raise their pay and improve their way of life isa key to money related consideration in India. As indicated by Singh (2008), microfinance administrations are intended to help the underprivileged to expand their pay, gives monetary solidness to run their life, with the assistance of the microfinance the retrogressive regions benefit the credit from the banks, the point of microfinance administrations is to serve for the underprivileged people[7]-[10].

Cull et al. (2008) found that there is an astounding achievement in keeping up high rates of advance reimbursement in microfinance division, however their investigation likewise recommends that benefit expanding speculators would have constrained enthusiasm for the greater part of the establishments that are concentrating on the most unfortunate clients and ladies, yet at the same time there is no undeniable reimbursement is finished by manygroups and furthermore the most elevated expenses and high exchange costsis charged.

Mayoux\&Hartl (2009) said that microfinance factor has contributing not exclusively to neediness decrease and money related maintainability, yet additionally increments monetary strengthening, and political strengthening for ladies themselves, along these lines tending to objectives of sex correspondence and strengthening. Mahajan and Bansal (2009) inferred that the effect of microfinance on ladies strengthening in Punjab and found that interest in microfinance have fundamentally expanded pay, yet has likewise created ordinary sparing propensities among ladies. As a result, ladies could effectively take an interest in family unit basic leadership, other than upgrading their social and mental empowerment.Dhanya\&Sivakumar (2010) remarked that regardless of the enhancements in reserve funds and banking propensities because of the support in microfinance programs, it likewise improved the countenances the issue of default, influencing the maintainability of the SHGs[11]-[14].

Emerlson (2011) found that the effect of microfinance program particularly through Self-Help Groups (SHGs) has been successful in rolling out positive social improvement to all individuals, regardless of the immediate borrowers of the smaller scale credit. Accordingly, microfinance is another instrument used to meet the credit prerequisite in rustic regions. It is being seen as a standout amongst the most useful assets for elevating the monetary states of the advantage less poor through gathering approach that guarantees dynamic interest and inclusion of the recipients in powerful execution of the program.

\section{RESEARCH METHODOLOGY}

Research configuration
received in this


investigation is descriptive[15]-[19]. The information gathered for this paper dependent on Primary and optional information. Information have been gathered through books and different sites and distributions of ongoing exploration papers accessible in various sites and magazines. Examining system embraced in this investigation is multi-organize inspecting and straightforward arbitrary testing to choose the respondents for the examination.The individuals from the SHG are taken as test from different regions and theory were tried dependent on the measurable apparatuses like Chi-square and ANOVA.

\section{RESULTS AND DISCUSSIONS}

Examination and elucidation are focal strides in the exploration procedure. The point of the investigation is to sort out, order and outline the gathered information so they can be better understood and deciphered to offer responses to the inquiries that set off the exploration. Translation is the look for the more extensive significance of discoveries. Investigation isn't satisfied without understanding; and translation can't continue without examination. In this way, both are bury subordinate. In this paper, a point by point examination of the gathered information has been endeavoured according to the destinations expressed before. Speculations were likewise tried dependent on the discoveries of the examination, elucidations and ends were drawn. In this part the accompanying measurable strategies, for example, chi-square, ANOVA are utilized for the examination of the information.

\section{A. Hypothesis1}

Null Hypothesis: There is no relationship between social advantages of SHG individuals according to involvement and Finance profited as acknowledge from the bank for regard to microfinance towards SHG's.

\begin{tabular}{|c|c|c|c|c|c|c|c|}
\hline \multirow{2}{*}{$\begin{array}{l}\text { Social benefits } \\
\text { of SHGs } \\
\text { members as } \\
\text { per } \\
\text { experience }\end{array}$} & \multicolumn{4}{|c|}{ Finance availed as credit from the bank } & \multirow[b]{2}{*}{ Total } & \multirow[b]{2}{*}{$\begin{array}{c}\text { Chi- } \\
\text { square } \\
\text { Value }\end{array}$} & \multirow[b]{2}{*}{ P Value } \\
\hline & $\begin{array}{l}\text { Below } \\
20000\end{array}$ & $\begin{array}{l}20000- \\
30000\end{array}$ & $\begin{array}{l}30000- \\
40000\end{array}$ & $\begin{array}{l}\text { Above } \\
40000\end{array}$ & & & \\
\hline $\begin{array}{l}\text { Participation in } \\
\text { social } \\
\text { activities }\end{array}$ & $\begin{array}{c}15 \\
(12.7 \%) \\
{[16.7 \%]}\end{array}$ & $\begin{array}{c}32 \\
(27.1 \%) \\
{[18.3 \%]}\end{array}$ & $\begin{array}{c}47 \\
(39.8 \%) \\
{[20.6 \%]}\end{array}$ & $\begin{array}{c}24 \\
(20.3 \%) \\
{[35.8 \%]}\end{array}$ & $\begin{array}{c}118 \\
(100.0 \%) \\
{[21.1 \%]}\end{array}$ & \multirow{6}{*}{77.670} & \multirow{6}{*}{$<0.001^{88}$} \\
\hline $\begin{array}{l}\text { Access to } \\
\text { financial } \\
\text { services }\end{array}$ & $\begin{array}{c}52 \\
(33.5 \%) \\
{[57.8 \%]}\end{array}$ & $\begin{array}{c}45 \\
(29.0 \%) \\
{[25.7 \%]}\end{array}$ & $\begin{array}{c}48 \\
(31.0 \%) \\
{[21.1 \%]}\end{array}$ & $\begin{array}{c}10 \\
(6.5 \%) \\
{[14.9 \%]}\end{array}$ & $\begin{array}{c}155 \\
(100.0 \%) \\
{[27.7 \%]}\end{array}$ & & \\
\hline $\begin{array}{l}\text { Social } \\
\text { awareness }\end{array}$ & $\begin{array}{c}14 \\
(11.0 \%) \\
{[15.6 \%]}\end{array}$ & $\begin{array}{c}45 \\
(35.4 \%) \\
{[25.7 \%]}\end{array}$ & $\begin{array}{c}45 \\
(35.4 \%) \\
{[19.7 \%]}\end{array}$ & \begin{tabular}{c|}
23 \\
$(18.1 \%)$ \\
{$[34.3 \%]$}
\end{tabular} & $\begin{array}{c}127 \\
(100.0 \%) \\
{[22.7 \%]}\end{array}$ & & \\
\hline $\begin{array}{l}\text { Increase in } \\
\text { social relation }\end{array}$ & $\begin{array}{c}5 \\
(5.6 \%) \\
{[5.6 \%]}\end{array}$ & $\begin{array}{c}32 \\
(35.6 \%) \\
{[18.3 \%]}\end{array}$ & $\begin{array}{c}49 \\
(54.4 \%) \\
{[21.5 \%]}\end{array}$ & $\begin{array}{c}4 \\
(4.4 \%) \\
{[6.0 \%]}\end{array}$ & $\begin{array}{c}90 \\
(100.0 \%) \\
{[16.1 \%]}\end{array}$ & & \\
\hline Social security & $\begin{array}{c}4 \\
(5.7 \%) \\
{[4.4 \%]}\end{array}$ & $\begin{array}{c}21 \\
(30.0 \%) \\
{[12.0 \%]}\end{array}$ & \begin{tabular}{c|}
39 \\
$(55.7 \%)$ \\
{$[17.1 \%]$}
\end{tabular} & $\begin{array}{c}6 \\
(8.6 \%) \\
{[9.0 \%]}\end{array}$ & $\begin{array}{c}70 \\
(100.0 \%) \\
{[12.5 \%]}\end{array}$ & & \\
\hline Total & $\begin{array}{c}90 \\
(16.1 \%) \\
{[100.0 \%]}\end{array}$ & \begin{tabular}{|c|}
175 \\
$(31.3 \%)$ \\
{$[100.0 \%]$}
\end{tabular} & $\begin{array}{c}228 \\
(40.7 \%) \\
{[100.0 \%]}\end{array}$ & $\begin{array}{c}67 \\
(12.0 \%) \\
{[100.0 \%]}\end{array}$ & $\begin{array}{c}560 \\
(100.0 \%) \\
{[100.0 \%]}\end{array}$ & & \\
\hline
\end{tabular}

Table 1 - Chi-square test for association between social benefits of SHG members as per experience and Finance availed as credit from the bank with respect to microfinance towards SHG's.

Note: 1 . The value within ( ) refers to Row Percentage

2. The value within [ ] refers to Column Percentage

3. * Denotes significant at $1 \%$ level

Since $P$ value is less than 0.01 , the null hypothesis is rejected at 1 percent level of significance.Hence, it is concluded that there is associationbetween social benefits of SHG members as per experience and Finance availed as credit from the bank with respect to microfinance towards SHG's. Based on the row percentage, participation in social activities $38.9 \%$ is high and the finance availed as credit from bank 30000 $40000,33.5 \%$ is high and the finance availed below 20000 Access to financial services and low at $6.5 \%$ above 40000 , social awareness is equal whose finance availing credit range from 20000-30000 and 30000-40000, 54.4\% increase in social relation and finance avail credit from banks is high and $4.4 \%$ is low, $55.7 \%$ is high at social security and the credit availability tends to be $30000-40000$ and $5.7 \%$ is low and credit avail from banks is below 20000.

\section{B. Hypothesis2}

Null Hypothesis: There is no association between social benefits of SHG members as per experience and Able to repay the loan in the scheduled repayment period with respect to microfinance towards SHG's.

\begin{tabular}{|c|c|c|c|c|c|}
\hline \multirow[t]{2}{*}{$\begin{array}{l}\text { Social benefits of } \\
\text { SHGs members as } \\
\text { per experience }\end{array}$} & \multicolumn{2}{|c|}{$\begin{array}{l}\text { Able to repay the } \\
\text { loan in the } \\
\text { scheduled } \\
\text { repayment period }\end{array}$} & \multirow[t]{2}{*}{ Total } & \multirow[t]{2}{*}{$\begin{array}{l}\text { Chi- } \\
\text { square } \\
\text { value }\end{array}$} & \multirow[t]{2}{*}{ P Value } \\
\hline & Yes & No & & & \\
\hline $\begin{array}{l}\text { Participation in } \\
\text { social activities }\end{array}$ & $\begin{array}{c}66 \\
(55.9 \%) \\
{[21.9 \%]}\end{array}$ & $\begin{array}{c}52 \\
(44.1 \%) \\
{[20.2 \%]}\end{array}$ & $\begin{array}{c}118 \\
(100.0 \%) \\
{[21.1 \%]}\end{array}$ & \multirow{6}{*}{91.476} & \multirow{6}{*}{$<0.001^{88}$} \\
\hline $\begin{array}{l}\text { Access to financial } \\
\text { services }\end{array}$ & $\begin{array}{c}92 \\
(59.4 \%) \\
{[30.5 \%]}\end{array}$ & $\begin{array}{c}63 \\
(40.6 \%) \\
{[24.4 \%]}\end{array}$ & $\begin{array}{c}155 \\
(100.0 \%) \\
{[27.7 \%]}\end{array}$ & & \\
\hline Social awareness & $\begin{array}{c}103 \\
(81.1 \%) \\
{[34.1 \%]}\end{array}$ & $\begin{array}{c}24 \\
(18.9 \%) \\
{[9.3 \%]}\end{array}$ & $\begin{array}{c}127 \\
(100.0 \%) \\
{[22.7 \%]}\end{array}$ & & \\
\hline $\begin{array}{l}\text { Increase in social } \\
\text { relation }\end{array}$ & $\begin{array}{c}22 \\
(24.4 \%) \\
{[7.3 \%]}\end{array}$ & $\begin{array}{c}68 \\
(75.6 \%) \\
{[26.4 \%]}\end{array}$ & $\begin{array}{c}90 \\
(100.0 \%) \\
{[16.1 \%]}\end{array}$ & & \\
\hline Social security & $\begin{array}{c}19 \\
(27.1 \%) \\
{[6.3 \%]}\end{array}$ & $\begin{array}{c}51 \\
(72.9 \%) \\
{[19.8 \%]}\end{array}$ & $\begin{array}{c}70 \\
(100.0 \%) \\
{[12.5 \%]}\end{array}$ & & \\
\hline Total & $\begin{array}{c}302 \\
(53.9 \%) \\
{[100.0 \%]}\end{array}$ & $\begin{array}{c}258 \\
(46.1 \%) \\
{[100.0 \%]}\end{array}$ & $\begin{array}{c}560 \\
(100.0 \%) \\
{[100.0 \%]}\end{array}$ & & \\
\hline
\end{tabular}

Table 2 -Chi-square test for association between social benefits of SHG members as per experience and Able to repay the loan in the scheduled repayment periodwith respect to microfinance towards SHG's.

Note: 1. The value within ( ) refers to Row Percentage

2. The value within [ ] refers to Column Percentage

3. * Denotes significant at $5 \%$ level

Blue Eyes Intelligence Engineering 
Since $\mathrm{P}$ value is $<0.01$, the null hypothesis is rejected at 1 percent level of significance.

Hence, it is concluded that there is association between social benefits of SHG members as per experience and Able to repay the loan in the scheduled repayment period with respect to microfinance towards SHG's. Based on the row percentage, participation in social activities and $55.9 \%$ said yes they are able to repay the loan within the scheduled time and $44.1 \%$ said no, 59.4\% Access to financial services agree yes and $40.6 \%$ says no, $81.1 \%$ gained social awareness and able to repay the loan, only $18.9 \%$ says no, $75.6 \%$ increase in social relation say no they are not able to repay the loan within time and only $24.4 \%$ say yes , $72.9 \%$ say no and they find it difficult $\mathrm{t}$ repay the loan under social security and only $27.1 \%$ say yes .

\section{Hypothesis 3}

Null Hypothesis: There is no association between social benefits of SHG members as per experience and Level of Role of MFS with respect to microfinance towards SHG's.

\begin{tabular}{|c|c|c|c|c|c|c|}
\hline \multirow{2}{*}{$\begin{array}{l}\text { Social benefits of } \\
\text { SHGs members as } \\
\text { per experience }\end{array}$} & \multicolumn{3}{|c|}{ Level of Role of MFS } & \multirow{2}{*}{ Total } & \multirow{2}{*}{$\begin{array}{l}\text { Chi- } \\
\text { square } \\
\text { value }\end{array}$} & \multirow[t]{2}{*}{ P Value } \\
\hline & Low & Moderate & High & & & \\
\hline $\begin{array}{l}\text { Participation in } \\
\text { social activity }\end{array}$ & $\begin{array}{c}34 \\
(28.8 \%) \\
{[22.2 \%]}\end{array}$ & $\begin{array}{c}55 \\
(46.6 \%) \\
{[20.6 \%]}\end{array}$ & $\begin{array}{c}29 \\
(24.6 \%) \\
{[20.7 \%]}\end{array}$ & $\begin{array}{c}118 \\
(100.0 \%) \\
{[21.1 \%]}\end{array}$ & \multirow{6}{*}{40.088} & \multirow{6}{*}{$<0.00188$} \\
\hline $\begin{array}{l}\text { Access to financial } \\
\text { services }\end{array}$ & $\begin{array}{c}28 \\
(18.1 \%) \\
{[18.3 \%]}\end{array}$ & $\begin{array}{c}66 \\
(42.6 \%) \\
{[24.7 \%]}\end{array}$ & $\begin{array}{c}61 \\
(39.4 \%) \\
{[43.6 \%]}\end{array}$ & $\begin{array}{c}155 \\
(100.0 \%) \\
{[27.7 \%]}\end{array}$ & & \\
\hline Social awareness & $\begin{array}{c}30 \\
(23.6 \%) \\
{[19.6 \%]}\end{array}$ & $\begin{array}{c}76 \\
(59.8 \%) \\
{[28.5 \%]}\end{array}$ & $\begin{array}{c}21 \\
(16.5 \%) \\
{[15.0 \%]}\end{array}$ & $\begin{array}{c}127 \\
(100.0 \%) \\
{[22.7 \%]}\end{array}$ & & \\
\hline $\begin{array}{l}\text { Increase in social } \\
\text { relation }\end{array}$ & $\begin{array}{c}30 \\
(33.3 \%) \\
{[19.6 \%]}\end{array}$ & $\begin{array}{c}44 \\
(48.9 \%) \\
{[16.5 \%]}\end{array}$ & $\begin{array}{c}16 \\
(17.8 \%) \\
{[11.4 \%]}\end{array}$ & $\begin{array}{c}90 \\
(100.0 \%) \\
{[16.1 \%]}\end{array}$ & & \\
\hline Social security & $\begin{array}{c}31 \\
(44.3 \%) \\
{[20.3 \%]}\end{array}$ & $\begin{array}{c}26 \\
(37.1 \%) \\
{[9.7 \%]}\end{array}$ & $\begin{array}{c}13 \\
(18.6 \%) \\
{[9.3 \%]}\end{array}$ & $\begin{array}{c}70 \\
(100.0 \%) \\
{[12.5 \%]}\end{array}$ & & \\
\hline Total & $\begin{array}{c}153 \\
(27.3 \%) \\
{[100.0 \%]}\end{array}$ & $\begin{array}{c}267 \\
(47.7 \%) \\
{[100.0 \%]}\end{array}$ & $\begin{array}{c}140 \\
(25.0 \%) \\
{[100.0 \%]}\end{array}$ & $\begin{array}{c}560 \\
(100.0 \%) \\
{[100.0 \%]}\end{array}$ & & \\
\hline
\end{tabular}

Table 3 - Chi-square test for association between social benefits of SHG members as per experience and Level of Role of MFS with respect to microfinance towards SHG's.

Note: 1 . The value within ( ) refers to Row Percentage

2. The value within [ ] refers to Column Percentage

3. * Denotes significant at $5 \%$ level

Since $\mathrm{P}$ value is $<0.01$, the null hypothesis is rejected at 1 percent level of significance.

\section{Hypothesis 4}

Null Hypothesis: There is no association between social benefits of SHG members as per experience and Level of Satisfaction on MFS with respect to microfinance towards SHG's.

\begin{tabular}{|c|c|c|c|c|c|c|}
\hline \multirow{2}{*}{$\begin{array}{l}\text { Social beotfis of } \\
\text { SHGs members } \\
\text { as per experienos }\end{array}$} & \multicolumn{3}{|c|}{ Level of Satiffaction on MrF } & \multirow{2}{*}{ Total } & \multirow{2}{*}{$\begin{array}{l}\text { Cli- } \\
\text { square } \\
\text { value }\end{array}$} & \multirow[t]{2}{*}{ PVatoe } \\
\hline & Lon: & Moderate & High & & & \\
\hline $\begin{array}{l}\text { Participation in } \\
\text { social activities }\end{array}$ & $\begin{array}{c}35 \\
(29.7 \%) \\
{[21.1 \%]}\end{array}$ & $\begin{array}{c}48 \\
(40.7 \%) \\
{[20.6 \%]}\end{array}$ & $\begin{array}{c}35 \\
(29.7 \%) \\
{[21.7 \%]}\end{array}$ & $\begin{array}{c}118 \\
(100.0 \%) \\
{[21.1 \%]}\end{array}$ & & \\
\hline $\begin{array}{l}\text { Access to } \\
\text { finsocial services }\end{array}$ & $\begin{array}{c}31 \\
(20.0 \%) \\
{[18.7 \%]}\end{array}$ & $\begin{array}{c}83 \\
(53.5 \%) \\
{[35.6 \%]}\end{array}$ & $\begin{array}{c}41 \\
(26.5 \%) \\
{[25.5 \%]}\end{array}$ & $\begin{array}{c}155 \\
(100.0 \%) \\
{[27.7 \%]}\end{array}$ & & \\
\hline $\mid$ Social amareoens & $\begin{array}{c}46 \\
(36.2 \%) \\
{[27.7 \%]}\end{array}$ & $\begin{array}{c}40 \\
(31.5 \%) \\
{[17.2 \%]}\end{array}$ & $\begin{array}{c}41 \\
(32.3 \%) \\
{[25.5 \%]}\end{array}$ & $\begin{array}{c}127 \\
(1000 \%) \\
{[22.7 \%]}\end{array}$ & & \\
\hline $\begin{array}{l}\text { Tocrease in socid } \\
\text { relation }\end{array}$ & $\begin{array}{c}24 \\
(26.7 \%) \\
{[14.5 \%]}\end{array}$ & $\begin{array}{c}48 \\
(53.3 \%) \\
{[20.6 \%]}\end{array}$ & $\begin{array}{c}18 \\
(20.0 \%) \\
{[11.2 \%]}\end{array}$ & $\begin{array}{c}90 \\
(100.0 \%) \\
{[16.1 \%]}\end{array}$ & 35.376 & $<0.001 * 4$ \\
\hline 3ocial securing & $\begin{array}{c}30 \\
42.9 \% \\
{[18.1 \%]}\end{array}$ & $\begin{array}{c}14 \\
(20.0 \%) \\
{[6.0 \%]}\end{array}$ & $\begin{array}{c}26 \\
(37.1 \%) \\
{[16.1 \%]}\end{array}$ & $\begin{array}{c}70 \\
(1000 \%) \\
{[12.5 \%]}\end{array}$ & & \\
\hline Total & $\begin{array}{c}166 \\
(29.6 \%) \\
{[100.0 \%]}\end{array}$ & $\begin{array}{c}233 \\
(41.6 \%) \\
{[100.0 \%]}\end{array}$ & $\begin{array}{c}161 \\
(28.5 \%) \\
{[100.0 \%]}\end{array}$ & $\begin{array}{c}560 \\
(1000 \%) \\
{[1000 \%]}\end{array}$ & & \\
\hline
\end{tabular}

Table 4 - Chi-square test for association between social benefits of SHG members as per experience and Level of Satisfaction on MFS with respect to microfinance towards SHGs.

Note: 1 . The value within ( ) refers to Row Percentage

2. The value within [ ] refers to Column Percentage

3. * Denotes significant at $1 \%$ level

Since $\mathrm{P}$ value is less than 0.01 , the null hypothesis is rejected at $1 \%$ level of significance.

Hence, it is concluded that there is association between social benefits of SHG members as per experience and Level of Satisfaction on MFS with respect to microfinance towards SHG's. Based on the row percentage, 29.7\%are high level of satisfaction on MFS ,40.7\% are moderate level satisfaction on MFS, $29.7 \%$ are low level of satisfaction on MFS for participation in social activities, $26.5 \%$ are high level of satisfaction in access to financial services, $53.5 \%$ are moderate level of satisfaction ,20\% are low level of satisfaction, $32.3 \%$ are high level of satisfaction on MFS in social awareness, $31.5 \%$ are moderate level,36.2\% are low level of satisfaction, $20 \%$ are high level of satisfaction, $53.3 \%$ are moderate level of satisfaction, $26.7 \%$ are low level of satisfaction for increase in social relation, $37.1 \%$ are high level of satisfaction on MFS, $20 \%$ are moderate level of satisfaction on MFS,42.9\% are low level of satisfaction on MFS for social security. It has been found that; majority of them said that level of satisfaction is moderate. With respect to factor participation in social activities and access to financial services, followed by low level of satisfaction on MFS with respect to factor social awareness, only few respondents said high level of satisfaction on MFS with factor respect to increase in social relation, social security factor seems tobe low level of satisfaction on MFS[20]-[22]. 
It has been observed that there is association between social benefits of SHG members and Level of Satisfaction on MFS with respect to microfinance towards SHG's, therefore level of satisfaction on MFS will vary according to factors of social benefits of SHG.

\section{E. Hypothesis 5}

Null Hypothesis: There is no significant difference among Educational Qualification with respect to Factors of Micro Finance System of SHG

\begin{tabular}{|c|c|c|c|c|c|c|c|}
\hline \multirow{2}{*}{$\begin{array}{l}\text { Factors of } \\
\text { Micro Finance } \\
\text { System }\end{array}$} & \multicolumn{5}{|c|}{ Edocational Qualification } & \multirow[b]{2}{*}{ F value } & \multirow[b]{2}{*}{ P ralue } \\
\hline & \begin{tabular}{|l} 
Iherats \\
\end{tabular} & Primary & $\begin{array}{l}\text { High } \\
\text { vebool }\end{array}$ & \begin{tabular}{|l} 
Fip: \\
Diploma
\end{tabular} & Grabsat: & & \\
\hline $\begin{array}{l}\text { Satur and } \\
\text { Contribution }\end{array}$ & $\begin{array}{l}35.39^{\prime} \\
(6.26)\end{array}$ & $\begin{array}{l}5555^{\circ} \\
(3.65)\end{array}$ & $\begin{array}{l}52.45^{\circ} \\
(6.65)\end{array}$ & $\begin{array}{l}35.13^{2} \\
(5.99)\end{array}$ & $\begin{array}{l}3210^{2} \\
(6.51)\end{array}$ & 16.364 & $<0.001 * 4$ \\
\hline Gsin Avaided & $\begin{array}{l}31.05^{\prime \prime} \\
(3.59)\end{array}$ & $\begin{array}{l}31.40^{\circ} \\
(5.07)\end{array}$ & $\begin{array}{l}29.65^{m} \\
(4.18)\end{array}$ & $\begin{array}{l}29 . T^{2} \\
(4.34)\end{array}$ & $\begin{array}{l}29.66^{\prime \prime} \\
(270)\end{array}$ & 5.402 & $<0.0014$ \\
\hline Perception & $\begin{array}{l}2952 \\
(4.29)\end{array}$ & $\begin{array}{l}28.44^{\circ} \\
(5.47)\end{array}$ & $\begin{array}{l}26.50^{\prime} \\
(4.76)\end{array}$ & $\begin{array}{l}26.57 \\
(4.59)\end{array}$ & $\begin{array}{l}25.75^{5} \\
(1.85)\end{array}$ & 9.511 & $<0.0014$ \\
\hline $\begin{array}{l}\text { Socio } \\
\text { Economic } \\
\text { Benefits }\end{array}$ & $\begin{array}{l}34.33^{\prime} \\
(4.22)\end{array}$ & $\begin{array}{l}35.94^{11} \\
(5.44)\end{array}$ & $\begin{array}{l}32.95^{m+1} \\
(4.63)\end{array}$ & $\begin{array}{l}32.27 \\
(4.64)\end{array}$ & $\begin{array}{l}32.44^{4} \\
(3.61)\end{array}$ & 3.697 & $0.005 * 4$ \\
\hline $\begin{array}{l}\text { Orerall opinion } \\
\text { on Mrs }\end{array}$ & $\begin{array}{l}15026^{\circ} \\
(15.01)\end{array}$ & $\begin{array}{l}152.16^{\circ} \\
(13.65)\end{array}$ & $\begin{array}{l}1419 \% \\
(16.35)\end{array}$ & $\begin{array}{l}14154^{+} \\
(15.76)\end{array}$ & $\begin{array}{l}159.95^{\circ} \\
(10.60)\end{array}$ & 12.603 & $<0.001 * 4$ \\
\hline $\begin{array}{l}\text { Sariffaction on } \\
\text { MrS }\end{array}$ & $\begin{array}{l}2405^{\prime} \\
(3.18)\end{array}$ & $\begin{array}{l}23.43^{m} \\
(4.63)\end{array}$ & $\begin{array}{l}22.67^{2} \\
(4.17)\end{array}$ & $\begin{array}{l}22.43^{2} \\
(3.96)\end{array}$ & $\begin{array}{l}22.35^{\prime \prime} \\
(2.81)\end{array}$ & 3.310 & $0.011^{*}$ \\
\hline $\begin{array}{l}\text { Self- } \\
\text { Development of } \\
\text { SHG }\end{array}$ & $\begin{array}{l}18.2 \% \\
(3.05)\end{array}$ & $\begin{array}{l}1735^{\circ} \\
(4.05)\end{array}$ & $\begin{array}{l}1752 \% \\
(3.79)\end{array}$ & $\begin{array}{l}17.17^{2} \\
(4.07)\end{array}$ & $\begin{array}{l}16.17^{2} \\
(2.76)\end{array}$ & 2922 & $0.021 *$ \\
\hline
\end{tabular}

Table 5 - ANOVA for significant difference among Educational Qualification with respect to Factors of Micro Finance System of SHG

Note: 1. The value within bracket refers to SD

2. ** denotes significant at $1 \%$ level.

3. * denotes significant at $5 \%$ level.

4. Different alphabet among Educational

Qualification denotes significant at 5\%

Level using Duncan Multiple Range Test (DMRT)

ANOVA was performed to locate the critical contrast among Educational Qualification regarding Factors of Micro Finance System of SHG. Since P esteem is under 0.01, invalid theory is rejected at $1 \%$ level with respect to the elements of Status and Contribution, Gain Availed, discernment, Socio Economic Benefits, Overall supposition on MFS. Thus there is importance distinction between instructive capability of individuals as to status and commitment, Gain Availed, observation, Socio Economic Benefits, in general conclusion on MFS. In light of Duncan Multiple Range Test (DMRT), the instructive capability of part uneducated is fundamentally varied with essential and secondary school at 5\% level, however there is no noteworthy contrast among essential and secondary school and furthermore HSc/Diploma and graduate in status and commitment, Gain Availed, discernment, Socio Economic Benefits, Overall feeling on MFS. Ignorant is altogether contrasted with essential and secondary school at 5\% level, yet there is no huge distinction among uneducated and secondary school and furthermore HSc/Diploma and graduate, in Overall elements of miniaturized scale account framework.

Since $\mathrm{P}$ esteem is under 0.05 , the invalid theory rejected at $5 \%$ level concerning Satisfaction on MFS, Self Development of SHG .Hence there is huge contrast among Overall components of miniaturized scale account framework with respect to Satisfaction on MFS, Self Development of SHG. In view of Duncan Multiple Range Test (DMRT), instructive capability of individuals uneducated is altogether varied with essential and secondary school at $5 \%$ level, however there is no critical contrast among essential and secondary school and furthermore HSc/Diploma and graduate in Satisfaction on MFS, Self Development of SHG. In view of Duncan Multiple Range Test (DMRT), HSc/Diploma and graduate is essentially contrasted with uneducated, and secondary school at 5\% level, however there is no huge distinction among ignorant and secondary school and furthermore H.Sc/Diploma and graduate, in Overall elements of miniaturized scale fund framework.

\section{F. Hypothesis 5}

Null Hypothesis: There is no significant difference among Monthly Family Income with respect to Factors of Micro Finance System of SHG

Table - 6 ANOVA for significant difference among Monthly Family Income

\begin{tabular}{|c|c|c|c|c|c|c|}
\hline \multirow{2}{*}{$\begin{array}{l}\text { Factors of Micro } \\
\text { Finance System }\end{array}$} & \multicolumn{4}{|c|}{ Monthly Family Income } & \multirow[b]{2}{*}{$\begin{array}{c}F \\
\text { Value }\end{array}$} & \multirow[b]{2}{*}{ P Value } \\
\hline & $\begin{array}{l}\text { Below } \\
10000\end{array}$ & $\begin{array}{l}10000- \\
15000\end{array}$ & $\begin{array}{l}15000- \\
20000\end{array}$ & $\begin{array}{l}\text { Above } \\
20000\end{array}$ & & \\
\hline Satas and Coctribusion & $\begin{array}{l}59.45^{\circ} \\
(3.09)\end{array}$ & $\begin{array}{l}56.63^{\circ} \\
(7.95)\end{array}$ & $\begin{array}{l}52.95^{4} \\
(6.07)\end{array}$ & $\begin{array}{l}54.40^{\circ} \\
(7.46)\end{array}$ & 14.724 & $<0.001 * 4$ \\
\hline Gain Avaded & $\begin{array}{l}35.33^{\circ} \\
(4.93)\end{array}$ & $\begin{array}{l}3050^{\circ} \\
(4.50)\end{array}$ & $\begin{array}{l}3009^{2} \\
(3.61)\end{array}$ & $\begin{array}{l}1991^{\circ} \\
(4.79)\end{array}$ & 10.763 & $<0.001 * 4$ \\
\hline Perception & $\begin{array}{l}3090^{\circ} \\
(4.25)\end{array}$ & $\begin{array}{l}23.4 O^{2} \\
(5.22)\end{array}$ & $\begin{array}{l}27.65^{\prime} \\
(3.39)\end{array}$ & $\begin{array}{l}2633^{2} \\
(5.26)\end{array}$ & 10922 & $<0.001 * 4$ \\
\hline $\begin{array}{l}\text { Socio Economic } \\
\text { Beneffts }\end{array}$ & $\begin{array}{l}36.35^{\circ} \\
(3.79)\end{array}$ & $\begin{array}{l}33.75^{*} \\
(4.79)\end{array}$ & $\begin{array}{l}33.69^{*} \\
(4.07)\end{array}$ & $\begin{array}{l}31.23^{*} \\
(5.55)\end{array}$ & 14.354 & $<0.001 * 4$ \\
\hline $\begin{array}{l}\text { Cverall of inise on } \\
\text { MrS }\end{array}$ & $\begin{array}{l}160.55^{\circ} \\
(18.33)\end{array}$ & $\begin{array}{l}149.25^{*} \\
(17.12)\end{array}$ & $\begin{array}{l}144.44^{*} \\
(14.24)\end{array}$ & $\begin{array}{l}141.87 \\
(17.39)\end{array}$ & 17.250 & $<0.001 * 4$ \\
\hline Saviffaction on Mrs & $\begin{array}{l}25.48 \\
(3.49)\end{array}$ & $\begin{array}{l}23.55 \\
(4.33)\end{array}$ & $\begin{array}{l}23.09 \\
(3.30)\end{array}$ & $\begin{array}{l}22.05^{\circ} \\
(4.21)\end{array}$ & 3.738 & $<0.001 * 4$ \\
\hline $\begin{array}{l}\text { Self Developmeat of } \\
\text { SHG }\end{array}$ & $\begin{array}{l}20.06^{\circ} \\
(3.01)\end{array}$ & $\begin{array}{l}17.34^{*} \\
(3.37)\end{array}$ & $\begin{array}{l}17.24^{*} \\
(3.12)\end{array}$ & $\begin{array}{l}16.41^{\circ} \\
(4.01)\end{array}$ & 12.106 & $-0.001 * 4$ \\
\hline
\end{tabular}

With respect to Factors of Micro Finance System of SHG

1. The value within bracket refers to SD

2. ** denotes significant at $1 \%$ level.

3. * denotes significant at $5 \%$ level.

4. Different alphabet among Monthly family Income denotes significant at $5 \%$ 
level using Duncan Multiple Range Test (DMRT)

ANOVA was performed to locate the huge contrast among Monthly Family Income concerning Factors of Micro Finance System of SHG. Since P esteem is under 0.01, invalid theory is rejected at $1 \%$ level with respect to the components of smaller scale fund framework, status and commitment, Gain profited, discernment, Socio Economic Benefits, in general supposition on MFS, Satisfaction on MFS, and Self improvement of SHG. Henceforth, there is hugeness contrast between month to month Income of individuals concerning status and commitment, Gain profited, observation, Socio Economic Benefits, Overall sentiment on MFS, Satisfaction on MFS, and Self advancement of SHG. In view of Duncan Multiple Range Test (DMRT), the month to month Income of part beneath 10000 and 10000-15000 is altogether contrasted with 15000-20000 or more 20000 at 5\% level, however there is no noteworthy distinction somewhere in the range of below10000 and 10000-15000 and furthermore 15000-20000 or more 20000 in status and commitment, Gain profited, observation, Socio Economic Benefits, in general supposition on MFS, Satisfaction on MFS, and Self improvement of SHG.below10000 is fundamentally varied with 15000-20000 or more 20000 at 5\% level, yet there is no huge distinction somewhere in the range of 10000 and 10000-15000 and also15000-20000 or more 20000, in Overall variables of small scale account framework.

It has been discovered that the social advantages factors and account benefited from the bank has relationship with one another[23]. Among the variables the most critical social advantages factor is access to money related administrations, trailed by the factor social mindfulness, etc, while contrasting the elements and life partner profited as credit from bank the SHG's are effectively getting to the budgetary administrations from banks as their credit for maintaining their business, and furthermore there is an improvement in the other social advantage components of the SHG's (Table $6.1)$

The SHG can reimburse the sum inside the timetable timeframe just a couple of think that its hard to reimburse inside time, among the social advantage factors the most noteworthy factor is social mindfulness, however a couple of them said there is an absence of increment in social connection and standardized savings, at the same time the respondents who are stating no to reimburse the sum inside planned time found that there is increment in social connection in this way the individuals are picking up advantages in the wake of participating in SHG's (Table6.2)

There is relationship between social benefits and job of MFS concerning microfinance, most of the respondents said that the job of MFS is fulfilled, most of the respondents says dimension of fulfillment is great with factor respect to access to money related administrations among the social advantages factors, the government disability factor is the least factor and individuals from SHG ailing in standardized savings which is certainly not a decent sign for the improvement of SHG, job of MFS as to this factor (Table 6.3). Greater part of them said that dimension of fulfillment is moderate regarding factor investment in social exercises and access to monetary administrations, trailed by low dimension of fulfillment on MFS as for factor social mindfulness, just couple of respondents said abnormal state of fulfillment on MFS with figure regard to expand social connection, government disability factor is by all accounts low dimension of fulfillment on MFS[24]. It has been seen that there is relationship between social advantages of SHG individuals and Level of Satisfaction on MFS as for microfinance towards SHG's, subsequently dimension of fulfillment on MFS will change as per elements of social advantages of SHG. (Table 6.4)

There is hugeness contrast between instructive capability of individuals as to status and commitment, Gain Availed, observation, Socio Economic Benefits, by and large conclusion on MFS; in rustic zones the training level will be low, because of the microfinance program the general population in the regressive territories picked up advantage as for the above variables[25]. It has additionally been seen that there is critical distinction among Overall variables of small scale fund framework as to Satisfaction on MFS, Self Development of SHG (Table 6.5)

It is found from the examination that there is criticalness distinction between month to month Income of individuals concerning components, for example, status and commitment, Gain profited, recognition, Socio Economic Benefits, Overall feeling on MFS, Satisfaction on MFS, and Self improvement of SHG. It is comprehended that the month to month salary of the individuals has expanded subsequent to participating in the SHG and it prompts improvement in the all the above factors(Table 6.6)

\section{RECOMMENDATIONS AND CONCLUSION}

In view of the investigation and discoveries in the examination, it is proposed that (1) there ought to be improvement in the social advantages picked up by the SHG, the microfinance program should build the government disability of the individuals and every one of the elements of social advantages ought to be given equivalent significance (2) the time planned to reimburse the sum ought to be reached out to individuals for gathering the sum so it lessens the weight of SHG individuals and improves the social relationship (3). It is presumed that there isassociationbetween social advantages of SHG individuals according to understanding and Level of Role of MFS concerning microfinance towards SHG's.It is proposed that (4) the dimension of fulfillment on MFS needs to increment to fulfil the individuals from SHG's and (5) the instructive capability of individuals in provincial territories must be improved, the microfinance methodology are not outstanding by individuals in reverse areas.

To finish up, the potential for developing miniaturized scale account foundations in India is high. Money related foundations need to teach locals on the simplicity of techniques for profiting advances.

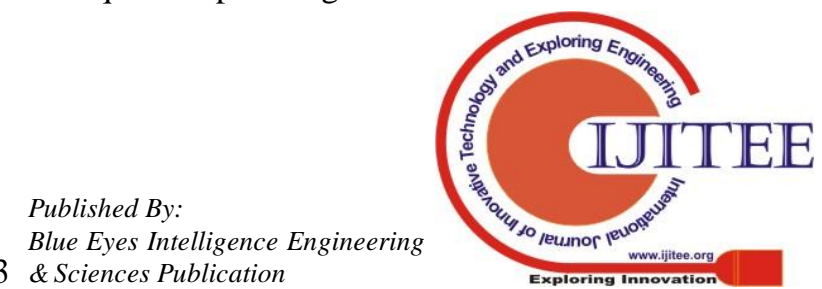


The reimbursement timetable ought to be intended to suit the regularity of individuals' pay (for example accessibility of cash after gather). Due weight ought to be given to SHGs on preparing the poor with vital aptitudes to end up productive cash chiefs and effective business visionaries by killing the money related and social imperatives looked by them. At the mass dimension mindfulness ought to be given about various plans supported by the Government. With the assistance of microfinance program the general population in the rustic divisions has picked up financial advantages which improved their salary, way of life and decrease neediness along these lines job of microfinance serves to advancement of SHG individuals in everyday life which prompts improvement of economy.

\section{REFERENCES}

1. Vasanthi, S. \& Rabiyathul Basariya, S. 2019, "Influence of value analysis and cross training in industry", International Journal of Engineering and Advanced Technology, vol. 8, no. 6, pp. 1810-1811.

2. Velvizhi, R., Sri Gowtham, S. \& Jeya Priya, D. 2019, "Examination of early feedbacks for effective product retailing on E-commerce websites", International Journal of Engineering and Advanced Technology, vol. 8, no. 6 Special Issue 2, pp. 703-706.

3. Anuradha, C., Pothumani, S. \& Kavitha, R. 2019, "A novel method towards E-commerce", International Journal of Engineering and Advanced Technology, vol. 8, no. 6 Special Issue 2, pp. 535-538.

4. Thomas, J. \& Rabiyathul Basariya, S. 2019, "A study on the issues of financial ratio analysis", Indian Journal of Public Health Research and Development, vol. 10, no. 3, pp. 1079-1081.

5. Ramachandran, S. \& Rabiyathul Basariya, S. 2019, "Online marketing study on customer satisfaction and relationship", Indian Journal of Public Health Research and Development, vol. 10, no. 3, pp. 1072-1078.

6. Priya, R., Vinothini, G. \& Cor Jesu, C.D. 2019, "The mentor-protégé relationship for professional growth", Journal of Advanced Research in Dynamical and Control Systems, vol. 11, no. 9 Special Issue, pp. 1110-1119.

7. Jannifer Rani, N., Bina Pani, S. \& Nimisha, N.S. 2019, "A study on money back polices available in LIC", Journal of Advanced Research in Dynamical and Control Systems, vol. 11, no. 9 Special Issue, pp. 833-839.

8. Saillaja, V., Jhansi Rani, K. \& Catherine, R. 2019, "Global marketing management planning and organization", Journal of Advanced Research in Dynamical and Control Systems, vol. 11, no. 9 Special Issue, pp. 489-493.

9. Saillaja, V., Jhansi Rani, K. \& Catherine, R. 2019, "The new phase of marketing information system", Journal of Advanced Research in Dynamical and Control Systems, vol. 11, no. 9 Special Issue, pp. 482-488.

10. Thoufiqulla \& Raju, D.V. 2019, "Perception of indian investor towards investment in mutual funds with special reference to mip funds", Journal of Advanced Research in Dynamical and Control Systems, vol. 11, no. 5, pp. 177-183.

11. Jasmine, K.R.M. \& Basariya, S.R. 2018, "A study on the customers benefits on mutual funds", International Journal of Civil Engineering and Technology, vol. 9, no. 4, pp. 45-48.

12. Vasanthi, S. \& Basariya, S.R. 2019, "Pros and cons of on the job training versus off the job training", International Journal of Scientific and Technology Research, vol. 8, no. 10, pp. 671-674.

13. Pavithra, J. \& Ganesan, M. 2016, "A study on awareness and impact of micro-financial schemes", International Journal of Applied Business and Economic Research, vol. 14, no. 8, pp. 5449-5460.

14. Pavithra, J., Dilli Babu, P. \& Ambuli, T.V. 2014, "A study on budgetary control at Maruti Service Masters, Chennai", International Journal of Applied Business and Economic Research, vol. 12, no. 2, pp. 151-161.

15. Gunaraja, T.M. \& Venkatrama Raju, D. 2018, "Determining factors of organisational climate with reference to leadership styles", International Journal of Mechanical Engineering and Technology, vol. 9, no. 9, pp. 1327-1332.

16. Gunaraja, T.M. \& Venkatrama Raju, D. 2018, "The role of job satisfaction and training of employees in determining organisational climate of a selected industry", International Journal of Civil Engineering and Technology, vol. 9, no. 8, pp. 1266-1269.

17. Aarathy, T.S. \& Raju, D.V. 2018, "Performance appraisal and its effects on employees with respect to it sector in Chennai city", International
Journal of Civil Engineering and Technology, vol. 9, no. 6, pp. 1535-1538.

18. Aarathy, T.S. \& Raju, D.V. 2018, "Employee perception towards performance appraisal system in IT sector", International Journal of Mechanical Engineering and Technology, vol. 9, no. 5, pp. 131-135.

19. Porselvi, W., Jublee, D. \& Sivanesan, G. 2018, "A study on factors influencing adoption of technology and innovation in banking industry, tamilnadu, India", International Journal of Mechanical Engineering and Technology, vol. 9, no. 5, pp. 789-800.

20. Akessa, G.M. and Dhufera, A.G., 2015. Factors That Influences Students Academic Performance: A Case of Rift Valley University, Jimma, Ethiopia. Journal of Education and Practice, 6(22), pp.55-63.

21. Miller, G. and Shih, C.C., 1999. A faculty assessment of the academic rigor of on-and off-campus courses in agriculture. Journal of Agricultural Education, 40, pp.57-65

22. Tsinidou, M., Gerogiannis, V. and Fitsilis, P., 2010. Evaluation of the factors that determine quality in higher education: an empirical study. Quality Assurance in education, 18(3), pp.227-244.

23. Farooq, M.S., Chaudhry, A.H., Shafiq, M. and Berhanu, G., 2011. Factors affecting students' quality of academic performance: a case of secondary school level. Journal of quality and technology management, 7(2), pp.1-14.

24. Fitsilis, P., Gerogiannis, V. and Anthopoulos, L., 2014. Ontologies for software project management: a review. Journal of Software Engineering and Applications, 7(13), p.1096.

25. Adams, J.D. and Jaffe, A.B., 1996. Bounding the effects of R\&D: an investigation using matched establishment-firm data(No. w5544). National bureau of economic research.

\section{AUTHORS PROFILE}

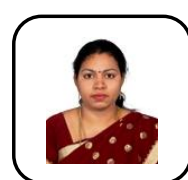

Anudevi Assistant Professor, Department of Science and Humanities, Bharath Institute of Higher Education and Research, Chennai , India

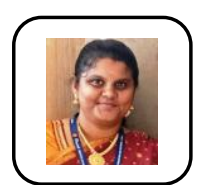

V.Sailaja Assistant Professor, Department of Science and Humanities, Bharath Institute of Higher Education and Research, Chennai , India.

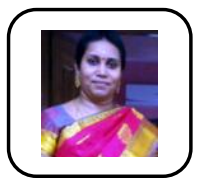

S.Binapani Assistant Professor, Department of Science and Humanities, Bharath Institute of Higher Education and Research, Chennai , India. 